\title{
Bir Hastanede Çalışan Yoğun Bakım Hemşirelerinde Tükenmişlik Düzeyinin Belirlenmesi
}

\section{Determining the Level of Burnout among the Intensive Care Nurses in a Hospital}

\section{Özet}

Amaç: Bu çalışmanın amacı, bir hastanenin yoğun bakım ünitesinde çalışan hemşirelerin tükenmişlik düzeylerini ve ilişkili bazı faktörleri belirlemektir.

Gereç ve Yöntemler. Bu kesitsel araştırma bir hastanenin yoğun bakım ünitesinde çalışan 90 hemşire ile Haziran 2012'de gerçekleştirilmiştir. Araştırmanın verileri, katılımcıların bazı sosyodemografık özelliklerini irdeleyen birtakım sorulardan ve Maslach Tükenmişlik Ölçeği'nden (MTÖ) oluşan bir anket formuyla toplanmıştır. Veriler SPSS 16.0 programında yüzdelik, tek yönlü varyans analizi, post hoc testleri (Tukey [HSD] çoklu karşılaştırma testi) ve bağımsız örneklem t-testi kullanılarak analiz edilmiş, p<0,05 olan değerler anlamlı kabul edilmiştir.

Bulgular. Bu çalışmada yer alan hemşirelerin \%93,3'ü kadındır ve \%60'ı 30-39 yaş aralığındadır. Meslekte çalışma süresi 6-10 yıl olan hemşirelerin kişisel başarı duygusundaki azalma puanlarının, meslekte çalışma süresi 1-5 yıl olan hemşirelere göre istatistiksel olarak anlamlı derecede yüksek olduğu saptanmıştır $(p=0,04)$. Vardiyalı çalışan hemşirelerin gündüz çalışanlara göre, meslek değiştirmeyi düşünen hemşirelerin diğer hemşirelere göre, ve iş yaşamından memnun olmayan hemşirelerin memnun olan hemşirelere göre duygusal tükenme puanlarının istatistiksel olarak anlamlı derecede yüksek olduğu saptanmıştır ( ırasıyla, $p=0,02 ; p<0,01 ; p<0,01$ ).

Tartışma ve Sonuç: Medeni durum, aylık gelir, çalışılan yıl sayısı, vardiyalı çalışma ve meslek değiştirmeyi düşünme yoğun bakım hemşirelerinin tükenmişlik düzeyini etkileyen önemli faktörler olarak belirlenmiştir.

Anahtar Kelimeler. hemşire; yoğun bakım; tükenmişlik

\begin{abstract}
Aim: The aim of this study is to determine the level of burnout among the intensive care nurses working in a hospital and some of the related factors.

Materials and Methods: This cross-sectional study was conducted with 90 nurses working in the intensive care unit of a hospital in June 2012. The data were collected with a questionnaire including a series of questions investigating the sociodemographic characteristics of the participants and the Maslach Burnout Inventory. The data were subjected to percentage analysis, one-way ANOVA, post hoc tests (Tukey's HSD test) and independent-samples t-test by using SPSS (Statistical Package for the Social Sciences) software, version 16.0. A p-value of $<0.05$ was considered statistically significant.

Results: Of the nurses, 93.3\% were female and 60\% aged between 30 and 39 years. It was observed that the nurses who had worked for 6 to 10 years scored statistically significantly higher on the feeling of reduced personal accomplishment subscale than the nurses who had worked for 1 to 5 years $(p=0.04)$. The nurses who worked in shifts compared to those who worked in the daytime, the nurses who were thinking about changing their jobs compared to those who were not, and the nurses who were satisfied with their careers compared to those who were not scored statistically significantly higher on the emotional exhaustion subscale $(p=0.02, p<0.01$, $p<0.01$, respectively).
\end{abstract}

Discussion and Conclusion: Marital status, the amount of monthly income, the number of working years, shift working, and thinking about changing jobs were determined as important factors affecting the level of burnout among intensive care nurses.

Key Words: nurse; intensive care; burnout
Galip Neşet Cerit' ${ }^{1}$ Güzin Aykal ${ }^{2}$, Aysun Güzel ${ }^{3}$,Inci Kara ${ }^{4}$

Antalya Eğitim ve Araştırma Hastanes Anesteziyoloji ve Reanimasyon Kliniği

Antalya Eğitim ve Araştırma Hastanesi Tıbbi Biyokimya Kliniği

${ }^{3}$ Mehmet Akif Ersoy Üniversitesi Sağlık

Yüksekokulu Acil Yardım ve Afet Yönetimi Bölümü

4 Selçuk Üniversitesi, Tıp Fakültesi, Anesteziyoloji ve Reanimasyon Kliniği

Gelis Tarihi /Received : 20.02 .2016 Kabul Tarihi /Accepted: 09.04.2016

Sorumlu Yazar/Corresponding Author Uzm. Dr. Galip Neşet Cerit

Antalya Eğitim ve Araştırma Hastanes Anesteziyoloji ve Reanimasyon Kliniği E-mail: drnesetcerit@gmail.com 


\section{GíRiş}

Tükenmişlik, modernleşme ve teknolojideki ilerlemenin bir sonucu olarak 1970 başlarında ABD'de kullanılmaya başlanmış ve ardından tüm toplumlar tarafından benimsenmiş bir terimdir (1). Günümüzde çalışanlar tarafından sıklıkla kullanılan "Ben, çok stres altındayım," "Benim bataryam boşaldı," "Ben çok tükendim” gibi ifadeler tükenmişlik haline atfedilmektedir. İşyerlerinde yaşanan, çalışanları psikolojik olarak etkileyen ve çalışma verimlerini düşüren çoğu olumsuz durum "tükenmişlik sendromu" adı verilen tablonun belirtileri olarak kabul edilmektedir (2).

Tükenmişlik sendromu genellikle çalışan bireyler için kullanılan ve fiziksel, duygusal ve zihinsel tükenme ile kendini gösteren bir durumdur. Tükenmişlik sonucunda çalışanlarda işe gitmeme, moral bozukluğu, uykusuzluk, alkol ve ilaç kullanımı ve ailevi problemlerde artış görülmektedir (3). Bu sorunlar, çalışanların mesleki performansını düşürmekte ve işyerinde uyumsuz insanlar olarak görülmelerine neden olmaktadır (4). Bu nedenlerle tükenmişlik sendromu; duygusal tükenme, duyarsızlaşma, çalışmanın verdiği hazzın azalışı ve kişilerarası ilişkilerin bozuluşuyla karakterize olan ve tüm bunlar sonucunda kişiyi yetersizliğe ve başarısızlığa iten bir meslek hastalığı olarak tanımlanmaktadır (2). Duygusal tükenme; yorgunluk, sinirlilik, dikkat eksikliği ve çeşitli psikosomatik belirtilerin arttığı durumdur. Duyarsızlaşma; kişinin diğer çalışanlardan uzaklaşması, kişilerarası ilişkiler kurmaması ve yalnızlaşması olarak ifade edilmektedir. Çalışmanın verdiği hazzın azalması ise çalışanın iş yerinde yaptı̆̆ işi severek yapmaması ve bunun sonucunda hem kendisi hem de işyeri açısından verimsizleşmesi ve kişisel başarısının azalması anlamına gelmektedir (5).

Tükenmişlik sendromu çalışanların işyerinde mutsuz ve verimsiz olmasina neden olarak onlara zarar vermektedir. Bu durumun yanı sıra sık hastalanma ya da ailevi, sosyal ve ekonomik problemlerin artması sonucunda işe gelememe, erken emekli olma, işyeri kazalarının artması, hizmet kalitesinin düşmesi ve sık iş değiştirme sorunlarını beraberinde getirerek işyerinin de maddi ve manevi kaybını artırmaktadır (6). Tükenmişlik sendromu maddi olarak tüm işyerlerini benzer biçimde etkilese de, tükenmişlik sendromuna yol açan manevi koşullar sağlık kuruluşlarında özellikle dikkat çekicidir. Tanık olunan acı ve ölümler, hasta insanları tedavi ederken oluşabilecek sorunlarla ilgili korku ve huzursuzluk hissi, hasta bakımının belirsizliği, uzun saatler çalışmanın verdiği kronik yorgunluk, kronik hastaların bitmeyen talepleri ve tüm bu yoğun çalışmanın altında kişilerarası ilişkilerin yetersizliği tükenmişlik sendromunun sağlık kuruluşlarında sık görülmesine neden olmaktadır $(7,8)$. Sağllk profesyonelleri arasında, çalışma şartlarının doğası gereği tükenmişlik sendromu en sık hemşirelerde görülürken, hemşireler arasında da en riskli grubun yoğun bakım hemşireleri olduğu vurgulanmaktadır (9). Yoğun bakımlarda yatan hastaların daha karmaşık ve bakımı zor olan hastalıklardan muzdarip olması, bu birimlerde çalışan hemşirelerin diğer hemşirelere göre ölmek üzere olan hastalarla daha fazla karşılaşması, daha stresli ve sıkıntılı bir ortamda çalışmaları ve bu nedenlerle de mesleki yeterliliklerinin diğer hemşirelerden fazla olmasının gerekliliği gibi durumlar, yoğun bakım hemşirelerinde tükenmişliğin diğer gruplardan daha fazla görülmesine neden olmaktadır (10-12). Bu sonuçlar doğrultusunda, yoğun bakım hemşirelerinin tamamen tükenmişlik seviyesine gelmelerini önlemek ya da var olan tükenmişlik seviyelerini belirlemek ve düşürmek için çalışmalar yapılması, hemşirelerin gelecekteki iş yaşamlarını olumlu etkileyebilir ve hastanelerde verilen hizmet kalitesini artırabilir. Bu çalışmada da bir hastanede çalışan yoğun bakım hemşirelerinin tükenmişlik düzeyinin belirlenmesi amaçlanmıştır.

\section{GEREÇ VE YÖNTEMLER}

Kesitsel tipteki bu çalışmanın evrenini, Haziran 2012'de bir hastanenin yoğun bakım ünitesinde çalışmakta olan 90 hemşire oluşturmuştur. Örneklem seçimine gidilmeyerek evrenin tamamı çalışma kapsamına alınmış ve tamamına ulaşılmıştır. Araştırmaya katılım düzeyi \%100’dür.

Araştırmada Maslach Tükenmişlik Ölçeğinden ve hemşirelerin bazı sosyodemografik özelliklerini sorgulayan 27 soruluk bir anket formundan oluşan bir veri toplama aracı kullanılmıştır.

Araştırmada yoğun bakım hemşirelerinin tükenmişlik düzeyini ölçmek amacıyla Maslach ve Jackson (1981) tarafından geliştirilen ve Ergin (1992) tarafın- 
dan Türkçeye uyarlanan Maslach Tükenmişlik Ölçeği kullanılmıştır (13). Bu ölçek, çalışanlarda tükenmişlik düzeyini ölçmekte kullanılan en yaygın yöntemdir. Ölçek; duygusal tükenme, kişisel başarı duygusunun azalması ve duyarsızlaşma olarak adlandırılan üç alt boyuttan oluşmuştur. Duygusal tükenme alt boyutu; çalışanların beklenti ve taleplerinin karşılanmaması, işyerinde motive edici faaliyetlerin olmaması ve kişiler arası ilişkilerin yetersiz olması nedeniyle hissedilenlerle ilgilidir. Duygusal tükenmenin uzun süre devam etmesi çalışanlarda duyarsızlaşmaya neden olmaktadır. Duyarsızlaşma alt boyutu, çalışanların işe ve işyerine kayıtsız olmalarının yanı sıra bakım ya da hizmet verirken aşağılayıcı ve kaba bir tutum içerisine girmeleriyle ilgilidir. Bu durumda olan çalışanlar kendilerine verilen görevleri başaramayacaklarına inanırlar, kendilerinin ve mesleki bilgilerinin yetersiz olduğunu düşünürler ve sonuçta başarısız olurlar. Kişisel başarı duygusunda azalma alt boyutu ise çalı̧sanların iş yerindeki performans düzeylerinden bahseder ve genel olarak diğer iki alt boyuta paralel bir şekilde gelişir (14). Ölçeğin duygusal tükenme alt boyutu 9 maddeden (1., 2., 3., 6., 8., 13., 14., 16. ve 20. sorular), kişisel başarı duygusunda azalma alt boyutu 8 maddeden (4., 7., 9., 12., 17., 18., 19. ve 21. sorular), duyarsızlaşma alt boyutu ise 5 maddeden (5., 10., 11., 15. ve 22. sorular) oluşmaktadır. Alt ölçek puanlamaları alt ölçek maddelerinin toplanmasıyla yapılmaktadır. Ölçek toplam puanı ise tüm ölçek maddelerinin toplanmasıyla elde edilmektedir. Ölçeğin yanıtlandırılışında 5’li derecelendirme kullanılmaktadır: Duygusal tükenme ve duyarsızlaşma alt boyutlarında "hiçbir zaman" (1 puan), "çok nadir" ( 2 puan), "bazen" (3 puan), "çoğu zaman" (4 puan), "her zaman" (5 puan) olarak belirlenmiştir. Kişisel başarı duygusunda azalma alt boyutunda ise puanlama "hiçbir zaman" (5 puan), "çok nadir" (4 puan),

Tablo 1. Araştırmaya katılan hemşirelerin, çalışma durumlarına ilişkin bazı özelliklerine göre dağılımı

\begin{tabular}{|c|c|c|c|}
\hline Hemşirelerin çalışma durumlarına ilişkin bazı özellikleri & & $\mathbf{n}$ & $\%$ \\
\hline \multirow{6}{*}{ Çalışılan birim } & Dahiliye Yoğun Bakım & 15 & 16,7 \\
\hline & Yenidoğan Yoğun Bakım & 19 & 21,1 \\
\hline & Reanimasyon Yoğun Bakım & 15 & 16,7 \\
\hline & Kardiyovasküler Cerrahi Yoğun Bakım & 13 & 14,4 \\
\hline & Koroner Yoğun Bakım & 13 & 14,4 \\
\hline & Cerrahi Yoğun Bakım & 15 & 16,7 \\
\hline \multirow{4}{*}{ Meslekte çalışma süresi (yıl) } & $1-5$ & 24 & 26,7 \\
\hline & $6-10$ & 48 & 53,3 \\
\hline & $11-15$ & 17 & 18,9 \\
\hline & $16-20$ & 1 & 1,1 \\
\hline \multirow{2}{*}{ Yoğun bakımda çalışılan toplam süre (yıl) } & $1-5$ & 61 & 67,8 \\
\hline & $6+$ & 29 & 32,2 \\
\hline \multirow{2}{*}{ Çalışma şekli } & Gündüz & 16 & 17,8 \\
\hline & Vardiya & 74 & 82,2 \\
\hline \multirow{3}{*}{ Haftalık ortalama çalışma saati } & $30-39$ & 2 & 2,2 \\
\hline & $40-49$ & 84 & 93,3 \\
\hline & $50+$ & 4 & 4,4 \\
\hline \multirow{4}{*}{$\begin{array}{l}\text { Çalışılan birimde bakımından sorumlu olunan } \\
\text { ortalama hasta sayısı }\end{array}$} & $1-3$ & 71 & 78,9 \\
\hline & $4-6$ & 12 & 13,3 \\
\hline & $7+$ & 3 & 3,3 \\
\hline & Cevapsiz & 4 & 4,4 \\
\hline \multirow{2}{*}{ Çalışılan bölüimüi tercih nedeni } & Kendi isteği & 55 & 61,1 \\
\hline & Yönetim kararı & 35 & 38,9 \\
\hline \multirow{4}{*}{ Mesleği seçme nedeni } & Ailesinin isteği ile & 29 & 32,2 \\
\hline & İş imkanı iyi olduğu için & 33 & 36,7 \\
\hline & Çevrenin etkisiyle & 10 & 11,1 \\
\hline & İsteyerek & 18 & 20,0 \\
\hline Toplam & & 90 & 100,0 \\
\hline
\end{tabular}


Tablo 2. Araştırmaya katılan hemşirelerin bazı özelliklerine göre dağılımı

\begin{tabular}{|c|c|c|c|}
\hline Hemşirelerin bazı özellikleri & & $\mathbf{n}$ & $\%$ \\
\hline \multirow{3}{*}{ Yaş } & $20-29$ & 30 & 33,3 \\
\hline & $30-39$ & 54 & 60,0 \\
\hline & $40-49$ & 6 & 6,7 \\
\hline \multirow{2}{*}{ Cinsiyet } & Erkek & 6 & 6,7 \\
\hline & Kadın & 84 & 93,3 \\
\hline \multirow{3}{*}{ Medeni durum } & Evli & 63 & 70,0 \\
\hline & Bekar & 26 & 28,9 \\
\hline & Dul & 1 & 1,1 \\
\hline \multirow{4}{*}{ Eğitim durumu } & Sağlık meslek lisesi & 7 & 7,8 \\
\hline & Ön lisans & 28 & 31,1 \\
\hline & Lisans & 53 & 58,9 \\
\hline & Lisansüstü & 2 & 2,2 \\
\hline \multirow{2}{*}{ Aylık gelirin yeterliliği } & Evet & 67 & 74,4 \\
\hline & Hayır & 23 & 25,6 \\
\hline \multirow{4}{*}{ Çocuk sayısı } & $1-2$ & 26 & 28,9 \\
\hline & $3-4$ & 18 & 20,0 \\
\hline & $5-6$ & 3 & 3,3 \\
\hline & Cevapsiz & 47 & 52,2 \\
\hline \multirow{3}{*}{ Halen yaşanılan yer } & Ailemle & 70 & 77,8 \\
\hline & Yalnız & 18 & 20,0 \\
\hline & Arkadaşlarımla & 2 & 2,2 \\
\hline \multirow[t]{2}{*}{ Kronik hastalığa sahip olma } & Evet & 15 & 16,7 \\
\hline & Hayır & 75 & 83,3 \\
\hline Toplam & & 90 & 100,0 \\
\hline
\end{tabular}

"bazen" (3 puan), "çoğu zaman" (2 puan), "her zaman" (1 puan) olarak hesaplanmaktadır. Ölçek alt boyutlarına göre duygusal tükenme alt boyutu için alınan 0-14 arasındaki puanlar "düşük," 15-22 arasındaki puanlar "normal," 23-36 arasındaki puanlar "yüksek;" duyarsızlaşma alt boyutu için alınan 0-8 arasındaki puanlar "düşük," 9-12 arasındaki puanlar "normal," 13-20 arasındaki puanlar "yüksek;" ve kişisel başarı duygusunda azalma alt boyutu için alınan 0-13 arasındaki puanlar "düşük," 14-19 arasındaki puanlar "normal," 20-32 arasındaki puanlar da "yüksek" sayılmaktadır. Toplamda en az 0, en çok 88 puana ulaşılmaktadır. Ölçekten alınan yüksek puanlar tükenmişliğin yüksek düzeyde olduğu şeklinde yorumlanmaktadır $(15,16)$.

Araştırmacılar tarafindan hazırlanan anket formu 27 sorudan oluşmaktadır. Bu sorular demografik verileri ölçen sorular (18 soru) ve tükenmişliğe ilişkin sorular (9 soru) olarak iki kategoride değerlendirilebilir. Verilecek yanıtlar ise boşluk doldurma, "evet/hayır" ve çoktan seçmeli şeklinde oluşturulmuştur.

Araştırma, Antalya Eğitim ve Araştırma
Hastanesi'nden yazılı izin ve çalışmaya katılmayı kabul eden hemşirelerin sözlü onamları alınarak gerçekleştirilmiştir. Araştırmaya katılmayı kabul eden hemşirelere gerekli açıklamalar yapıldıktan sonra 2012 Haziran ayında anket formları dağıtılmış ve anketler doldurulduktan sonra 2012 Ağustos ayında geri toplanmıştır. Eksik ya da yanlış doldurulan anket formlarına rastlanılmamıştır.

Veriler SPSS 16.0 programında yüzdelik, tek yönlü varyans analizi, post hoc testleri (Tukey [HSD] çoklu karşılaştırma testi) ve bağımsız örneklem $t$-testi kullanılarak analiz edilmiş, $\mathrm{p}<0,05$ olan değerler anlamlı kabul edilmiştir.

\section{BULGULAR}

Hemşirelerin sosyodemografik özellikleri, çalışma durumları ve yaşam kalitelerine ilişkin bazı özellikleri Tablo 1, 2 ve 3’te verilmiştir.

Araştırmaya katılan hemşirelerin \%60'1 30-39 yaş aralığındadır ve \%93,3'ü kadındır. Araştırmaya katılan 
Anadolu Klin / Anatol Clin

Tablo 3. Araştırmaya katılan hemşirelerin yaşam kalitelerine ilişkin bazı özelliklerine göre dağılımı

\begin{tabular}{|c|c|c|c|}
\hline Hemşirelerin yaşam kalitelerine ilişkin bazı özellikleri & & n & $\%$ \\
\hline \multirow{3}{*}{ Mesleği değiștirme düşüncesi } & Koşullar uygun olursa & 49 & 54,4 \\
\hline & İlk firsatta & 12 & 13,3 \\
\hline & Emekliliğe kadar & 29 & 32,2 \\
\hline \multirow{3}{*}{ Toplam aylık gelirin yeterliliği } & Hayır & 23 & 25,6 \\
\hline & Evet/kısmen & 66 & 73,3 \\
\hline & Evet/tamamen & 1 & 1,1 \\
\hline \multirow{2}{*}{ Psikolojik destek alma durumu } & Evet & 14 & 15,6 \\
\hline & Hayır & 78 & 84,4 \\
\hline \multirow{4}{*}{ İşs stresiyle başa çıkmada tercih edilen eylem } & Hobi & 21 & 23,3 \\
\hline & Kültürel faaliyetler & 31 & 34,4 \\
\hline & Spor & 4 & 4,4 \\
\hline & Hiçbiri & 34 & 37,8 \\
\hline \multirow{2}{*}{ İşs stresi nedeniyle işe gitmeme durumu } & Evet & 0 & 0 \\
\hline & Hayır & 90 & 100,0 \\
\hline \multirow{3}{*}{ Hasta bakımında kendini yeterli görme durumu } & Yeterli & 66 & 73,3 \\
\hline & Kismen yeterli & 23 & 25,6 \\
\hline & Yetersiz & 1 & 1,1 \\
\hline \multirow{3}{*}{ Tatil yapma sıklı̆̆ı } & Tatil yapmiyor & 16 & 17,8 \\
\hline & Yılda 1 kez & 64 & 71,1 \\
\hline & Yllda iki kez & 10 & 11,1 \\
\hline \multirow{3}{*}{ İş yerine ulaşım şekli } & Yürüyerek & 32 & 35,6 \\
\hline & Toplu taşıma aracıyla & 40 & 44,4 \\
\hline & Kendi arabasıyla & 18 & 20,0 \\
\hline \multirow{3}{*}{ Genel olarak iş yaşamından memnun olma durumu } & Evet & 12 & 13,3 \\
\hline & Kismen & 57 & 63,3 \\
\hline & Hayır & 21 & 23,3 \\
\hline \multirow{4}{*}{ Mesleği olumsuz olarak eleştirme sıklığı } & Siklıkla & 32 & 35,6 \\
\hline & Bazen & 45 & 50,0 \\
\hline & Nadiren & 11 & 12,2 \\
\hline & Hiçbir zaman & 2 & 2,2 \\
\hline \multirow{2}{*}{$\begin{array}{l}\text { Geçmişe dönmek mümkün olsa yine yoğun bakım } \\
\text { hemşireliğini seçme durumu }\end{array}$} & Evet & 58 & 64,4 \\
\hline & Hayır & 32 & 35,6 \\
\hline Toplam & & 90 & 100,0 \\
\hline
\end{tabular}

hemşirelerin \%70’i evli ve \%58,9’u sağlık meslek lisesi mezunudur, \%74,4'ü aylık gelirini yeterli bulmaktadir ve $\% 28,9^{\prime}$ u 1 ya da 2 çocuğa sahiptir. Araştırmaya katılan hemşirelerin $\% 77,8$ 'i ailesiyle yaşamaktadır ve $\% 83,3$ 'ünün kronik bir hastalığı bulunmamaktadır (Tablo 1)

Araştırmaya katılan hemşirelerin \%21,1'i yenidoğan yoğun bakım ünitesinde çalışmaktadır. Araştırmaya katılan hemşirelerin \%53,3'ünün meslekte çalışma süresi 6-10 yıl, \%67,8'inin yoğun bakımda çalışma süresi 1-5 yıl, \%82,2'sinin çalışma şekli vardiya, \%93,3'ünün haftalık ortalama çalışma süresi 40-49 saat, \%78,9'unun bulunduğu birimde bakımından so- rumlu olduğu hasta sayısı 1-3 kişidir. \%61,1'inin çalışlan bölümü tercih nedeni kendi isteği, \%36,7'sinin mesleği seçme nedeni iş imkanın iyi oluşudur (Tablo 2).

Araştırmaya katılan hemşirelerin \%54,4'ü koşullar uygun olursa mesleğini değiştirmek istediğini ifade etmiştir. Araştırmaya katılan hemşirelerin \%73,3'ü aylık gelirinin yeterliliği konusunda "evet/kısmen," \%84,4'ü psikolojik destek alıp almadığı sorusuna "hayır," \%34,4'ü iş stresiyle başa çımada tercih ettiği eylem için "kültürel faaliyetler," \%100'ü iş stresi nedeniyle işe gitmezlik edip etmediği sorusuna "hayır," \%73,3'ü hasta bakımında kendini yeterli görmek ko- 
Tablo 4. Hemşirelerin Maslach Tükenmişlik Ölçeği ve alt boyutlarından aldıkları puanların dağılımı

\begin{tabular}{|l|c|c|c|}
\hline \multirow{2}{*}{ MTÖ boyutları } & Olası puanlar & \multicolumn{2}{|c|}{ Gözlenen puanlar } \\
\cline { 2 - 4 } & En düşük-En yüksek & En düşük-En yüksek & Ort \pm Standart sapma \\
\hline Duygusal tükenme & $0,00-36,00$ & $0,00-34,00$ & $19,14 \pm 6,06$ \\
\hline Duyarsılaşma & $0,00-20,00$ & $0,00-14,00$ & $5,93 \pm 3,38$ \\
\hline Kişisel başarı duygusunda azalma & $0,00-32,00$ & $0,00-22,00$ & $13,00 \pm 3,79$ \\
\hline Toplam & $0,00-88,00$ & $51,00-87,00$ & $66,02 \pm 7,62$ \\
\hline
\end{tabular}

nusunda “yeterli," \%17,8’i tatil yapma sıklığı için “tatil yapmıyorum," \%44,4'ü iş yerine nasıl ulaştığ sorusuna "toplu taşıma aracı"” \%63,3’ü genel olarak iş yaşamından memnun olup olmadığı sorusuna “kısmen," \%50'si mesleğini olumsuz olarak eleştirme sıklı̆̆ı için "bazen" ve \%64,4'ü geçmişe dönmek mümkün olsa yine yoğun bakım hemşireliği mesleğini seçip seçmeyeceği sorusuna "evet" yanıtını vermiştir (bkz. Tablo 3).

Tablo 4’te görüldüğü üzere, araştırmaya katılan hemşirelerin MTÖ boyutlarından duygusal tükenme alt boyutundan aldıkları en düşük puan 0,00 ve aldıkları en yüksek puan 34,00 olup, ortalama puan-

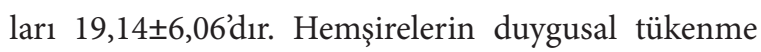
durumları "normal" bulunmuştur. Araştırmaya katılan hemşirelerin MTÖ boyutlarından duyarsızlaşma alt boyutunda aldıkları en düşük puan 0,00 ve aldıkları en yüksek puan 14,00 olup, ortalama puanları 5,93 33,38'dir. Hemşirelerin duyarsızlaşma durumları "düşük" bulunmuştur. Araştırmaya katılan hemşirelerin MTÖ boyutlarından kişisel başarı duygusunda azalma alt boyutunda aldıkları en düşük puan 0,00 ve aldıkları en yüksek puan 22,00 olup, ortalama puanları 13,00 \pm 3,79'dur. Hemşirelerin kişisel başarı duygusunda azalma durumları "düşük" bulunmuştur. Hemşirelerin MTÖ toplam puanlarına bakıldığında aldıkları en düşük puan 51,00 ve aldıkları en yüksek puan 87,00 olup, ortalama puanları 66,02 $\pm 7,62$ 'dir. Hemşirelerin tükenmişlik durumları “yüksek” bulunmuştur.

Tablo 5’te görüldüğü üzere, araştırmaya katılan hemşirelerin medeni durumları ile MTÖ puanları karşılaştırıldığında, bekar olan hemşirelerin evli olan hemşirelere göre duyarsızlaşma alt boyutu puanları istatistiksel olarak anlamlı bir biçimde yüksek çıkmıştır $(\mathrm{p}=0,03)$.

Araştırmaya katılan hemşirelerin aylık gelirlerinin yeterliliği ile MTÖ puanları karşılaştırıldığında, aylık gelirinin yetersiz olduğunu ifade eden hemşirelerin yeterli olduğunu ifade eden hemşirelere göre duyarsız- laşma alt boyutu puanları istatistiksel olarak anlamlı bir biçimde düşük çıkmıştır ( $\mathrm{p}=0,01)$.

Araştırmaya katılan hemşirelerin çalıştıkları birim ile MTÖ puanları karşılaştırıldığında; dahiliye yoğun bakım, reanimasyon yoğun bakım ve koroner yoğun bakım ünitelerinde çalışan hemşirelerin, cerrahi yoğun bakım ünitesinde çalışan hemşirelere göre duyarsızlaşma alt boyutu puanları istatistiksel olarak anlamlı bir şekilde düşük bulunmuştur $(\mathrm{p}=0,01)$.

Hemşirelerin yoğun bakımda çalıştıkları toplam yıl sayısı ile MTÖ puanları karşılaştırıldığında; 6-10 yıl çalışan hemşirelerin, 1-5 yıl arasında çalışan hemşirelere göre kişisel başarı duygusunda azalma puanları istatistiksel olarak anlamlı bir şekilde yüksek bulunmuştur $(\mathrm{p}=0,03)$.

Hemşirelerin çalışma şekli ile MTÖ puanları karşılaştırıldığında, çalışma şekli vardiya olan hemşirelerin, çalışma şekli gündüz olan hemşirelere göre duygusal tükenme alt boyutu puanları istatistiksel olarak anlamlı bir şekilde yüksek bulunmuştur $(p=0,02)$.

Hemşirelerin meslek değiştirme düşünceleri ile MTÖ puanları karşılaştırıldığında, meslek değiştirme için "ilk fursatta" diyen hemşirelerin, "koşullar uygun olursa" ve "emekliliğime kadar burada çalışırım" diyen hemşirelere göre duygusal tükenme puanları istatistiksel olarak anlamlı biçimde yüksek bulunmuştur $(\mathrm{p}=$ $0,01)$.

Hemşirelerin iş yaşamlarından memnuniyetleri ile MTÖ puanları karşılaştırıldığında; iş yaşamından memnun olup olmadiğı sorusuna "hayır" diyen hemşirelerin "evet" ve "kısmen" diyen hemşirelere göre, "kısmen" diyen hemşirelerin "evet" diyen hemşirelere göre duygusal tükenmişlik alt boyutu puan ortalamaları yüksek bulunmuştur ( $\mathrm{p}=0,01)$. Yine aynı karşılaştırmada iş yaşamından memnun olup olmadığı sorusuna "hayır" diyen hemşirelerin, "evet" ve "kısmen" diyen hemşirelere göre kişisel başarı duygusunda azalma puanları istatistiksel olarak anlamlı bir şekilde düşük 
Tablo 5. Hemşirelerin bazı özellikleri ile Maslach Tükenmişlik Ölçeği ortalamalarının dağılımı ve anlamlılık (p) düzeyleri

\begin{tabular}{|c|c|c|c|c|c|c|c|c|}
\hline \multirow{3}{*}{\multicolumn{2}{|c|}{ Özellikler }} & \multirow[b]{3}{*}{$\mathbf{n}$} & \multicolumn{6}{|c|}{ Maslach Tükenmişlik Ölçeği } \\
\hline & & & \multicolumn{2}{|c|}{ Duygusal tükenme } & \multicolumn{2}{|c|}{ Duyarsızlaşma } & \multicolumn{2}{|c|}{$\begin{array}{c}\text { Kişisel başarı } \\
\text { duygusunda azalma }\end{array}$} \\
\hline & & & Ort \pm SS & $t-F / p$ & Ort \pm SS & $t-F / p$ & Ort \pm SS & $t-F / p$ \\
\hline \multirow{2}{*}{ Medeni durum* ${ }^{*}$} & Evli & 63 & \multirow{2}{*}{\multicolumn{2}{|c|}{---}} & $10,44 \pm 3,3$ & $-211 /$ a 0.03 & \multirow{2}{*}{\multicolumn{2}{|c|}{---}} \\
\hline & Bekar & 27 & & & $12,07 \pm 3,2$ & $-2,11 / \cdots, 03$ & & \\
\hline \multirow{2}{*}{ Aylık gelirin yeterliliği } & Evet & 67 & \multirow{2}{*}{\multicolumn{2}{|c|}{---}} & $11,56 \pm 3,4$ & & \multirow{2}{*}{\multicolumn{2}{|c|}{---}} \\
\hline & Hayır & 23 & & & $9,08 \pm 2,4$ & $-3,72 / a 0,01$ & & \\
\hline \multirow{6}{*}{ Çalışılan birim } & Dahiliye Yoğun Bakım & 15 & \multirow{6}{*}{\multicolumn{2}{|c|}{---}} & $10,06 \pm 3,1$ & & \multirow{6}{*}{\multicolumn{2}{|c|}{---}} \\
\hline & Yenidoğan Yoğun Bakım & 19 & & & $10,84 \pm 3,7$ & & & \\
\hline & $\begin{array}{l}\text { Reanimasyon Yoğun } \\
\text { Bakım }\end{array}$ & 15 & & & $9,60 \pm 2,4$ & & & \\
\hline & $\begin{array}{l}\text { Kardiyovasküler Cerrahi } \\
\text { Yoğun Bakım }\end{array}$ & 13 & & & $11,30 \pm 3,4$ & $3,846 /{ }^{\circ} 0,01$ & & \\
\hline & Koroner Yoğun Bakım & 13 & & & $9,76 \pm 2,7$ & & & \\
\hline & Cerrahi Yoğun Bakım & 15 & & & $13,93 \pm 3,2$ & & & \\
\hline \multirow{3}{*}{$\begin{array}{l}\text { Meslekte çalışma süresi } \\
(y \mathbf{l})^{\star *}\end{array}$} & $1-5$ & 24 & \multirow{3}{*}{\multicolumn{2}{|c|}{---}} & \multirow{3}{*}{\multicolumn{2}{|c|}{---}} & $25,66 \pm 3,5$ & \multirow{3}{*}{$3,094 /{ }^{\mathrm{b}} 0,04$} \\
\hline & $6-10$ & 48 & & & & & $26,97 \pm 3,9$ & \\
\hline & $11-15$ & 18 & & & & & $28,55 \pm 3,3$ & \\
\hline \multirow{2}{*}{$\begin{array}{l}\text { Yoğun bakımda çalışılan } \\
\text { toplam süre (yıl) }\end{array}$} & $1-5$ & 61 & \multirow{2}{*}{\multicolumn{2}{|c|}{--- }} & \multirow{2}{*}{\multicolumn{2}{|c|}{---}} & $26,34 \pm 3,5$ & $-2,21 /$ \\
\hline & $6-10$ & 29 & & & & & $28,20 \pm 4,0$ & ${ }^{\mathrm{a}} 0,03$ \\
\hline \multirow{2}{*}{ Çalışma Şekli } & Gündüz & 16 & $24,75 \pm 5,2$ & \multirow{2}{*}{$-2,52 /{ }^{a} 0,02$} & \multirow{2}{*}{\multicolumn{2}{|c|}{---}} & \multirow{2}{*}{\multicolumn{2}{|c|}{--- }} \\
\hline & Vardiya & 74 & $28,87 \pm 6,0$ & & & & & \\
\hline \multirow{3}{*}{$\begin{array}{l}\text { Meslek değiştirme } \\
\text { düşüncesi }\end{array}$} & Koşullar uygun olursa & 49 & $29,02 \pm 5,7$ & \multirow{3}{*}{$4,986 /{ }^{\mathrm{b}} 0,01$} & \multirow{3}{*}{\multicolumn{2}{|c|}{---}} & \multirow{3}{*}{\multicolumn{2}{|c|}{---}} \\
\hline & İlk firsatta & 12 & $31,00 \pm 5,7$ & & & & & \\
\hline & Emekliliğe kadar & 29 & $25,48 \pm 6,0$ & & & & & \\
\hline \multirow{3}{*}{$\begin{array}{l}\text { İș yaşamından } \\
\text { memnun olma durmu }\end{array}$} & Evet & 12 & $22,33 \pm 5,2$ & & & & $28,16 \pm 4,1$ & \\
\hline & Kismen & 57 & $27,45 \pm 5,1$ & $18,72 /{ }^{\mathrm{b}} 0,01$ & & -- & $27,59 \pm 3,7$ & $6,579 /{ }^{\mathrm{b}} 0,01$ \\
\hline & Hayır & 21 & $33,33 \pm 5,2$ & & & & $24,47 \pm 2,6$ & \\
\hline Geçmişe & Evet & 58 & $26,82 \pm 5,5$ & & & & $27,74 \pm 3,5$ & \\
\hline $\begin{array}{l}\text { dönülebilseydi } \\
\text { tekrar yoğun bakım } \\
\text { hemşireliğini seçme } \\
\text { durumu }\end{array}$ & Hayır & 32 & $30,53 \pm 6,4$ & $-2,86 /{ }^{a} 0,01$ & & -- & $25,50 \pm 3,9$ & $2,76 /{ }^{a} 0,01$ \\
\hline
\end{tabular}

${ }^{a}$ Bağımsız örneklem $t$-testi.

${ }^{\text {b } T e k ~ y o ̈ n l u ̈ ~ v a r y a n s ~ a n a l i z i ~ v e ~ T u k e y ~(H S D) ~ c ̧ o k l u ~ k a r s ̧ ı l a s ̧ t ı r m a l ı ~ t e s t i . ~}$

* Dul olan bir kişi "bekar" grubuna eklenmiștir.

** Çalışma süresi 16-20 yıl olan bir kişi çalışma süresi 11-15 olan gruba dahil edilmiștir.

bulunmuştur $(\mathrm{p}=0,01)$.

Hemşirelerin geçmişe dönmek mümkün olsa yine yoğun bakım hemşireliğini seçip seçmeyeceği sorusuna verdikleri yanıtlar ile MTÖ puanları karşılaştırıldığında; "hayır" diyen hemşirelerin "evet" diyen hemşirelere göre duygusal tükenme alt boyutu istatistiksel olarak anlamlı bir şekilde yüksek bulunmuştur $(\mathrm{p}=0,01)$. Yine aynı karşılaştırmada "hayır" diyen hemşirelerin "evet" diyen hemşirelere göre kişisel başarı duygusunda azalma alt boyutu puanları istatistiksel olarak anlamlı bir şekilde yüksek bulunmuştur $(\mathrm{p}=0,01)$.

\section{TARTIŞMA VE SONUÇ}

Ülkemizde özellikle sağlık sektöründe tükenmişlikle ilgili yapılan çalışmalar çok fazladır ve genellikle doktorlar ve hemşirelerle gerçekleştirilmiştir. Çalışmaların içerikleri incelendiğinde yıpranma riski diğer hemşirelerden yüksek olan yoğun bakım hemşirelerinde yapılan tükenmişlik çalışmalarının yetersiz olduğu görülmüştür. $\mathrm{Bu}$ araştırma ise bir hastanenin yoğun bakım biriminde çalışan hemşireler üzerinde gerçekleştirilmiştir.

Yaptığımız araştırmada, bekar hemşirelerin evli olanlara göre duyarsızlaşma puanları daha yüksek çıkmıştır. Sağlık çalışanlarıyla ilgili literatür incelen- 
diğinde yapılan bazı araştırmalar bulduğumuz sonuca paralellik gösterirken $(17,18)$, bazı araştırmalarda ise medeni durum ve duyarsızlaşma arasında bir ilişki bulunamamıştır $(19,20)$. Duyarsızlaşma; başkalarına karşı tutum ve davranışların değişmesine, insanlardan uzaklaşmaya ve sonuç olarak da yalnızlığa yol açan bir durumdur (21). Evli bireyler sorunlarını paylaştıkları, sorun çözmek için beraber hareket ettikleri ve sorumlulukları beraber üstlendikleri bir hayat arkadaşına sahiptirler. Bekar bireyler ise sorunlarını genellikle kendileri halletmeye çalışmakta, eğer sorun içinden çıkılmaz bir hale gelmişse aileleri ile paylaşmaktadırlar. Dolayısıyla işyerinde sorun yaşayan bekar hemşirelerin, evli olanlara göre hayattan kopmaya ve insanlardan uzaklaşmaya daha meyilli olması beklenebilir.

Yaptığımız araştırmada aylık gelirinin yeterli olduguunu düşünen hemşirelerin yetersiz olduğunu düşünen hemşirelere göre duyarsızlaşma puanları yüksek çıkmıştır. Sağlık çalışanlarıyla yapılan bazı çalışmalarda aylık gelirinin yeterli olduğunu düşünenlerin duyarsızlaşma puanları düşük çıkmıştır $(19,22,23)$. Araştırma sonucumuz literatüre uymamaktadır. Gelirin yeterli olması, kişinin sosyalliğini artıran, yalnızlıktan uzaklaştıran bir faktör olarak ifade edilmektedir (24). Bulduğumuz sonucun bu durumun aksi olması ise araştırmanın sadece yoğun bakım ünitesinde yapılmasından ya da katılımcıların sahip oldukları bireysel özelliklerinden olabilir.

Yaptığımız araştırmada cerrahi yoğun bakım ünitesinde çalışan hemşirelerin duyarsızlaşma alt boyutu puanları dahiliye yoğun bakım, reanimasyon yoğun bakım ve koroner yoğun bakım ünitelerinde çalışan hemşirelere göre yüksek bulunmuştur. Yoğun bakım ünitesinde yapılan başka bir araştırmada cerrahi yoğun bakım ünitesinde çalışan hemşirelerde duyarsızlaşma puanı en yüksek, koroner yoğun bakım ünitesinde çalışan hemşirelerde duyarsızlaşma puanı en düşük bulunmuştur (25). İki araştırma sonucu birbirini desteklemektedir. Yoğun bakımda yatan hastalar ölümle yaşam arasında mücadele veren, çeşitli destekleyici cihazların varlığına ihtiyaç duyan ve müdahale edilmesi zor hastalardır. Yoğun bakıma kabul edilen hastaların \%21'i cerrahi nedenlerle alınmaktadır (26). Diğer birim ve yoğun bakım üniteleriyle karşılaştırıldığında, cerrahi işlem geçiren hastaların aile bireyleri cerrahi işlem sırasında ve sonrasında kaygı ve anksiye- te duymaktadırlar. Bu durumda da cerrahi servislerde ve cerrahi yoğun bakım ünitesinde görev yapan hemşirelerin hasta bakımının yanı sıra kaygılı aile bireylerine bilgi vermesi ve destek olması da beklenmektedir (27). Cerrahi yoğun bakım ünitelerinde hastanın kalış süresi 1-34 gün arasında değişirken yapılan bir araştırmada hastaların \%83,3'ünün 1-3 gün arasında taburcu olduğu saptanmıştır (28). Genel olarak yoğun bakım ünitelerinin hepsinde zor şartlarda çalışılmaktadır; fakat cerrahi yoğun bakım ünitelerinde hasta bakımının yanı sıra hasta yakınlarına bilgi verme zorunluluğunun da doğması ve hasta sirkülasyonunun fazla olması, bu birimlerde çalışan hemşirelerin soğuk, ilgisiz ve katı bir tutum içine girerek karşısındakilere kaba davranmasına ve onlara gerekli yardımı sağlamaktan kaçınmasına, yani duyarsızlaşmasına neden olabilir.

Hemşirelerin, profesyonel benliklerini kazanmaları ve meslekle özdeşleşmeleri öğrencilik yıllarında başlar ve çalışma yaşamı süresince devam eder. Profesyonel benlik gelişimi olumlu olduğunda hemşirelerin nitelikleri, kişisel başarıları ve iş doyumları artarken tükenmişlik düzeyleri de azalmaktadır (29). Bu durumu destekler biçimde, sağlık çalışanlarıyla yapılan bazı çalışmalarda çalışılan yıl sayısı arttıkça kişisel başarının da arttığ görülmüştür $(18,30,31)$. Yaptığımız araştırmada ise yoğun bakımda çalıştıkları toplam süre 6-10 yıl olan hemşirelerin, toplam 1-5 yıl çalışmış olan hemşirelere göre kişisel başarı duygusunda azalma puanları yüksek bulunmuştur. Araştırma sonucumuz literatür ile uyumlu değildir. Uzun yıllar aynı birimde çalışan hemşirelerin mesleki yeterlilik ve deneyimlerinin aynı birimde çalışan diğer hemşirelere göre fazla olması beklenmektedir. Yaptığımız araştırmada bu durumun tersinin ortaya çıkması, sağlık çalışanlarıyla yapılan araştırmaların yürütüldüğü hastanelerdeki sağlık çalışanlarının yaşlarının ve yaş ortalamalarının farklı olmasından ya da hastanelerdeki yoğun bakım ünitelerinde yatan hasta sayılarının ve niteliklerinin birbirinden farklı olmasından kaynaklanabilir.

Vardiyalı çalışanların biyolojik, psikolojik ve sosyal yaşamları olumsuzlaşmakta, uyku bozukluğu ve yorgunluk gibi faktörler devreye girmektedir. Vardiyalı çalışma; iş başarısının düşmesine, iş kazalarının artmasına ve tükenmişliğe neden olarak işyerinde işe devamsızlık sorununun ortaya çımasına neden olmak- 
tadır (32). Yaptığımız araştırmada, çalışma şekli vardiya olan hemşirelerin çalışma şekli gündüz olan hemşirelere göre duygusal tükenme puanları yüksek bulunmuştur. Hemşirelerle yapılan başka bir araştırmada da vardiya usulü çalışan hemşirelerde duygusal tükenme puanları yüksek bulunmuştur (31). Yapılan başka bir araştırmada ise sağlık çalışanlarının aylık nöbet sayılarına göre tükenmişlik düzeylerine bakıldığında, 1-5 gün nöbeti olanların hiç nöbeti olmayanlara göre duygusal tükenme puanları daha yüksek bulunmuştur (22). Araştırma sonuçları birbirini desteklemektedir. Vardiyalı çalışanların yaşadıkları fiziksel ve ruhsal sorunlar yıpranma, enerji kaybı, işe devamsızlıkta artış ve tükenme gibi sorunlara yol açabilir.

Yaptığımız araştırmada, "ilk fırsatta” mesleğini değiştirmeyi düşündüğünü bildirenlerin "koşullar uygun olursa, emekliliğime kadar burada çalışırım” diyenlere göre duygusal tükenme puanları yüksek bulunmuştur. Sağlık çalışanlarıyla yapılan diğer araştırmalarda da mesleğini değiştirmeyi düşünen hemşirelerin duygusal tükenme puanları diğer hemşirelere göre yüksek bulunmuştur $(23,33,34)$. Hemşirelerin çalıştıkları birimlerde mesleklerini sürdürme isteklerinin düzeyi, o birimde hissettikleri haz ve başarı duygusuna göre değişebilir. Hemşireler mutsuz olduklarında, iş kazalarında artış, anksiyete ve depresyon gibi durumlar daha sık görülebilir ve mesleklerini değiştirmek istemelerine rağmen değiştiremeyen hemşirelerde ise tükenmişlik duygusu ortaya çıkabilir.

Yaptığımız araştırmada, iş yaşamından memnun olup olmadığı sorusuna "hayır" diyen hemşirelerin "evet" ve "kismen" diyen hemşirelere göre duygusal tükenmişlik puanları yüksek bulunmuştur. Sağlık çalışanlarıyla yapılan diğer araştırmalarda da iş yaşamından memnun olmayanların duygusal tükenmişlik puanları yüksek bulunmuştur $(22,33)$. Duygusal tükenme, tükenmişlik durumunun en önemli bileşenidir (21). İş yaşamından memnun olmayan çalışanların üzerlerinde hissettikleri iş stresi, huzursuzluk ve enerji kaybina neden olabilir ve bu durum da duygusal tükenmişlikle sonuçlanabilir.

Yaptığımız araştırmada, "geçmişe dönülebilseydi tekrar yoğun bakım hemşireliğini seçer miydiniz?" sorusuna "hayır" diyen hemşirelerin "evet" diyen hemşirelere göre duygusal tükenme puanları yüksek bulunmuştur. Yapılan çeşitli araştırmalarda mesleğini rastlantılar sonucunda ya da istemeden seçen sağlık çalışanlarında duygusal tükenme puanları yüksek bulunmuştur (22,25,31). Araştırma sonucumuz literatür ile uyumludur. İstemediği birimlerde çalışan hemşirelerin huzursuzluk ve stres yaşamaları, çalıştıkları alanda kendilerini geliştirmek istememeleri doğal kabul edilirken, yoğun bakım gibi stresli bir birimde çalışanlar için bu durum tükenmişliğe neden olabilir.

Sonuç olarak araştırmamızda bekar olan, aylık geliri yeterli olan, cerrahi yoğun bakımda çalışan hemşirelerin duyarsızlaşma puanları; meslekte çalıştığı yıl sayısı fazla olan hemşirelerin kişisel başarı duygusunda azalma puanları; vardiyalı çalışan ve mesleğini ilk firsatta değiştirmeyi düşünen hemşirelerin ise duygusal tükenme puanları yüksek bulunmuştur.

$\mathrm{Bu}$ sonuçlar doğrultusunda mesleğe yeni başlamış olan bekar hemşirelerin yoğun bakım üniteleri gibi zorlu çalışma şartları olan ve pratik bilgi gerektiren klinikler yerine deneyim ve soğukkanlılık kazanabilecekleri diğer kliniklerde görev alması daha uygun olabilir.

Hemşireler tarafından hasta yakınlarına sürekli bilgi verilen cerrahi yoğun bakım servislerinde, ameliyattan çıkan hastaların monitöre yansıtılan isimlerinin yanına ameliyat sonrası durumlarını belirten birkaç bilgi yazılması hemşirelerin iş yükünü azaltabilir. Ayrıca yoğun bakım ünitelerinde hizmet içi eğitimler düzenlenmesi mesleğe yeni başlamış olan hemşirelerin kişisel başarılarını artırabilir; yoğun bakım ünitelerinde vardiya şartları ve çalışma saatlerinin düzenlenmesi, ortamın çalışanların ihtiyaçlarına göre düzenlenmesi ve bu birimlerde çeşitli etkinlikler yapılması hemşirelerde tükenmişlik durumunu azaltabilir ve mesleklerini sevmelerine yardımcı olabilir.

\section{KAYNAKLAR}

1. Schaufeli WB, Leiter MP, Maslach C. Burnout: 35 years of research and practice. Career Dev Int. 2009;14(3):20420.

2. Weber A, Reinhard AJ. Burnout syndrome: a disease of modern societies? Occup Med. 2000;50(7):512-7.

3. Maslach J, Jackson SE. The measurement of experienced burnout. J Occup Behav. 1981;2(2): 99-113.

4. Schutte N, Toppinen S, Kalimo R, Schaufeli W. The factorial validity of the Maslach Burnout Inventory-General Survey (MBI-GS) across occupational groups and nations. J Occup Organ Psychol. 2000;73(1):53-66. 
5. Pustułka-Piwnik A, Jan Ryn1 Z, Krzywoszański L, Stożek J. Burnout syndrome in physical therapists: demographic and organizational factors. Medycyna Pracy. 2014;65(4):453-62.

6. Galanakis M, Moraitou M, Garivaldis FJ, Stalikas A. Factorial structure and psychometric properties of the Maslach Burnout Inventory (MBI) in Greek midwives. Eur J Psychol. 2009;4:52-70.

7. Ogresta J, Rusac S, Zorec L. Relation between burnout syndrome and job satisfaction among mental health workers. Croat Med J. 2008;49(3):364-74.

8. Zanatta AB, Lucca SR. Prevalence of Burnout syndrome in health professionals of an onco-hematological pediatric hospital. Rev Esc Enferm USP. 2015;49(2):251-8.

9. Khamisa N, Peltzer K, Oldenburg B. Burnout in relation to specific contributing factors and health outcomes among nurses: a systematic review. Int J Environ Res Public Health. 2013;10(6): 2214-40.

10. Chitura D, Chitura M. Burnout Syndrome In Intensive Care Unit Nurses In Zimbabwe. ESJ. 2014;(Aug/special/ ed):436-57.

11. Embriaco N, Papazian L, Kentish-Barnes N, Pochard F, Azoulay E. Burnout syndrome among critical care healthcare workers. Curr Opin Crit Care. 2007;13(5):482-8.

12. Bakker AB, Le Blanc PM, Scahaufeli WB. Burnout contagion among intensive care nurses. J Adv Nurs. 2005;51(3):276-87.

13. Çapri B. Tükenmişlik ölçeğinin Türkçe uyarlaması: geçerlik ve güvenirlik çalışması. Mersin Üniversitesi Eğitim Fakültesi Derg. 2006;2(1):62-77.

14. Schaufeli WB, Salanova M. Efficacy or inefficacy, that's the question: burnout and work engagement, and their relationships with efficacy beliefs. Anxiety Stress Coping. 2007;20(2):177-96.

15. Erşan EE, Doğan O, Doğan S. Analyzing of factors related to burnout in health professionals of Sivas Numune Hospital. Cumhuriyet Med J. 2011;33(1):33-41.

16. Sağlam Arı G, Çına Bal E. Tükenmişlik kavramı: birey ve örgütler açısından önemi. Yönetim ve Ekonomi: Celal Bayar Üniversitesi İktisadi ve İdari Bilimler Fakültesi Dergisi. 2008;15(1):131-48.

17. Demir S. Ankara Üniversitesi Tip Fakültesi hastaneleri çalışanlarının tükenmişlik ve iş doyumu düzeylerinin bazı değişkenler açısından incelenmesi [yüksek lisans tezi]. Ankara: Atılım Üniversitesi Sosyal Bilimler Enstitüsü; 2010.

18. Türk Tabipler Birliği. Türkiye'de Tabip Odalarına Kayıtlı Olan Bir Grup Hekimde Tükenmişlik Sendromu ve Etkileyen Faktörler. Ankara: Türk Tabipler Birliği Yayınları; 2005.

19. Süloğlu A. Diyaliz merkezlerinde çalışan doktor ve hemşirelerde tükenmişlik sendromu [uzmanlık tezi]. İstanbul: 2009.
20. Erol A, Akarca F, Değerli V, Sert E, Delibaş H, Gülpek D, et al. Acil servis çalışanlarında tükenmişlik ve iş doyumu. Klinik Psikiyatri Derg. 2012;15(2):103-10.

21. Aktaş E. Anestezi ve dahili klinik çalışanlarında depresyon ve tükenmişlik sendromu açısından karşılaştırılması [uzmanlık tezi]. Diyarbakır: Dicle Üniversitesi Tip Fakültesi Anesteziyoloji ve Reanimasyon Anabilim Dalı; 2013

22. Oğuzberk M, Aydın A. Ruh sağlığı çalışanlarında tükenmişlik. Klinik Psikiyatri Derg. 2008;11(4):167-79.

23. Barutçu E, Serinkan C. Günümüzün önemli sorunlarından biri olarak tükenmişlik sendromu ve Denizli'de yapılan bir araştırma. Ege Akademik Bakış. 2008;8(2):54161.

24. Çalışkan Ş. Türkiye'de gelir eşitsizliği ve yolsuzluk. Sosyal Siyaset Konferanslar1. 2010;59(2):89-132.

25. Dizer B, İyigün E, Kılıç S. Yoğun bakım hemşirelerinin tükenmişlik düzeylerinin belirlenmesi. Yoğun Bakım Hemşireliği Derg. 2008;12(1-2):1-11.

26. Hatipoğlu S. Cerrahi yoğun bakım hemşireliği ilkeleri. Gülhane Tip Dergisi. 2002;44(4):475-9.

27. Uzun Ö, Özer N, Çevik Akyıl R. Bazı cerrahi kliniklerde ve cerrahi yoğun bakım ünitelerinde yatan hastaların ailelerinin gereksinimleri. Atatürk Üniversitesi Tip Derg. 2002;34(2): 39-45.

28. Kurucu NM, Efil S, Eser O, Aslan A, Karabekir HS. Beyin cerrahi yoğun bakım ünitesinde yatan hastaların retrospektif olarak değerlendirilmesi. Balikesir Sağlık Bilimleri Derg. 2013;2(2):79-84.

29. Sabancıoğulları S, Doğan S. Bir üniversite hastanesinde çalışan hemşirelerin profesyonel benlik gelişim düzeyleri ve etkileyen faktörler. Anadolu Hemşirelik ve Sağlık Bilimleri Derg. 2014;17(1):15-22.

30. Yakut Hİ, Gül Kapısız S, Durutuna S, Evran A. Sağlık Alanında Çalışma Yaşamında Tükenmişlik. JGON. 2013;10(38):1564-71.

31. Altay B, Gönener D, Demirkıran C. Bir üniversite hastanesinde çalışan hemşirelerin tükenmişlik düzeyleri ve aile desteğinin etkisi. Firat Tip Derg. 2010;15(1):10-6.

32. Yüksel İ. Çalışma yaşamı kalitesinin tipik ve atipik istihdam açısından incelenmesi. Doğuş Üniversitesi Derg. 2004;5 (1):47-58

33. Şentürk S. Yoğun bakım hemşirelerinin tükenmişlik düzeyleri ile uyku kalitesi arasındaki ilişkinin incelenmesi. Bozok Tip Derg. 2014;4(3):48-56.

34. Sayıl I, Haran S, Ölmez Ş, Özgüven HD. Ankara Üniversitesi hastanelerinde çalışan doktor ve hemşirelerin tükenmişlik düzeyleri. Kriz Derg. 1997;5(2):71-7. 